\title{
Street children and volatile substance misuse
}

\author{
Letter from Brazil
}

\author{
John Dunn
}

\begin{abstract}
Living in London one gets used to seeing teenagers living rough on the streets, sleeping in shop doorways, and begging for money. Similarly in São Paulo and other large cities in Brazil homeless and destitute children are a common sight, but there are several striking differences. First, in Brazil there are many more of them, they are noticeably younger and they are often seen doing some form of job or 'bicos' to earn money, such as cleaning shoes or car windows, 'guarding' cars, and selling small items, e.g. sweets, fruits and flowers. Another important difference is the danger to which these children are exposed. There have been frequent reports, some of which have reached the international media, of street children being massacred by vigilantes (some of whom have links with the police).
\end{abstract}

The Brazilian charity FUNABEM estimated in 1987 that there were seven million abandoned children living on the streets in Brazil. But street children are a heterogeneous group and not all of them have been abandoned; some still have varying degrees of contact with their families (Forster et al, 1992). If one includes these children in the estimate the figure rises to 10-30 million, a staggering $20 \%$ of the population!

These children have been extensively studied by researchers in the social sciences, anthropology and drug misuse fields. A common story is of a family who have migrated from the poorer northern states to the richer southern cities in search of a better life, only to be met by shanty towns or favelas, unemployment and further poverty. Paternal alcoholism and violence in the home are often described. There is little schooling and by the age of 10 the child has either been abandoned or leaves the home because of the intolerable conditions. Such children congregate in small groups with their own internal hierarchy. Days are spent trying to obtain money by doing odd jobs, begging, theft or robbery. There is the constant threat of violence, especially at night when they are sleeping, and many of these children have been shot by vigilantes and the police. There are night-shelters, both state-run

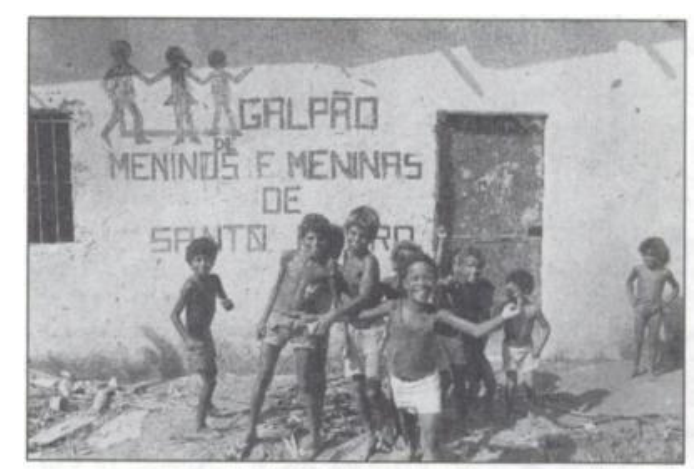

Children in Peixinhos shanty town, Recife, Brazil. Photograph by Carlos Reyes. Copyright Andes Press Agency.

and voluntary, where a bed, food and bathing facilities are available, but provision is inadequate to meet the needs of the huge number of homeless children. The physical health of these children is poor. Lebensztajn et al (1986) examined 143 children from a night shelter in São Paulo and discovered a range of illnesses and conditions, such as orthopaedic abnormalities $(68 \%)$, dental caries (59\%), pubic lice (57\%), anaemia (34\%), scabies (18\%) and inflammatory processes $(17 \%)$.

Drug misuse in this population is both extremely common and very visible and consists primarily of inhaling shoemaker's glue, cola de sapatetro, from a plastic bag. This takes place on the streets and in public squares. The prevalence of volatile substance misuse among this population has been found to be between 43-100\%. Many studies looking at the problem have tended to focus on the toxicological aspects, e.g. type of substance used and the side-effects, or on the demographic details of the users (Carlini et al, 1988 and Pedrozo \& Siqueira, 1989). More recent studies though have tried to examine, sometimes in a more qualitative way, the lives of these children, factors which protect against drug 
misuse, and possible solutions to the problem. One particular study in addition to collecting demographic data and information about drug misuse also tried to discover more about the lives, experiences, attitudes and expectations of these children and as a consequence gives results which are both interesting and at times touching (Bucher et al, 1991).

The study took place in Ceilândia, a satellite city to the Brazilian capital. Brasilia. One hundred and fifty children aged between 10 and 17 were interviewed. Fifty were living on the street, 50 in an institution for delinquent and conduct disordered children and $\mathbf{5 0}$ controls from a state school. Most of the information discussed here regards the street children although some comparisons are made with the school children.

The mean age of the street children was 13 . They had had little schooling, 88\% not having completed the primeiro grau (age 7-14) and 66\% had started working before the age of 10 . Only $20 \%$ had parents living in Cellandia and for $38 \%$ their parents were living outside the state altogether. The families usually originated from the northeast of Brazil, but as Cellâdia is a new city so did the majority of the school children's parents. The street children often mentioned that their fathers had abused alcohol (58\%), their mothers had had nervous problems (32\%) and there was a family history of violence and delinquency.

Drug use among these children centred around the inhalation of volatile substances, for $84 \%$ this was the first drug ever used (compared with $4 \%$ of the school children, $90 \%$ of whom had never used any drug) and was also the drug they mostly commonly continued to use (86\%). Eighty-eight per cent of the street children using volatile substances were using one particular type of glue - shoemakers glue (cola de sapatetro) which is one of the cheapest and most accessible forms. Forty-eight per cent were using volatile substances on a daily basis and $40 \%$ at least weekly. It was usually inhaled from a plastic bag (84\%) and was an activity performed in small social groups (68\%). Carlini-Cotrim \& Carlini (1987) found more evidence of polydrug misuse among a sample of 120 street children in São Paulo, $60 \%$ were using marijuana, $58 \%$ the anticholinergic drug Artane and $16 \%$ cocaine but solvents remained the most commonly used drug (93\%).

The reasons for using volatile substances varied but reflected a wish to escape from the situation and conditions in which they were living and experience something better; common reasons included: "to get high", "to feel happy or to laugh", "to fly, to run or jump", "to dream" and "to endure".

Most of the street children did some form of work, such as cleaning shoes, guarding cars or selling small items. The overwhelming majority wished that they could continue to study and dreamt of having a better job, such as a driver, a policeman, a barman, a bank clerk and even a doctor or lawyer. The main reasons given for these choices were not simply to earn more money but because they thought such work would be interesting and give them the independence and freedom that they lacked.

One of the conclusions of this and other studies of drug use among street children is that it would be wrong simply to see the misuse of volatile substances as a 'drug problem'. The answer does not simply lie in making substances, such as shoemaker's glue, more difficult to get hold of or more expensive. The solution lies with politicians and social/educational policies, in particular getting children off the streets and into school and some form of supportive and protective environment and re-establishing or re-enforcing family links where this is possible. Other studies from Brazil have clearly demonstrated the protective effect of family contact and school in relation to drug misuse and delinquency. But social policies like these are expensive and although Brazil is rich in natural resources, its massive international debts mean that much of its food and money flows into so-called 'first world' countries instead of into the mouths and pockets of its own population.

\section{References}

BUCHER, R., COSTA, A.C.L. \& OLIVEIRA. J.A. (1991) Consumo de inalantes e condicőes de vida de menores da periferla de Brasília. Revista ABP-APAL, 13, 18-26.

CARLINI-COTRIM, B. \& CARLINI, E.A. (1987) O consumo de solventes e outras drogas em crianças e adolescentes de baixa renda na Grande São Paulo. Part II: Meninos de rua e menores internados. Revista ABP-APAL, 9, 69-77.

CARLINI, E.A., CARLINI-COTrIM, B. \& Monteiro, M.G. (1988) Abuso de solventes voláteis: aspectos epidemiológia, medico-psicológla e experimentais. Revista da Associação Médica Brasileira, 34, 61-67.

FORSTER, L.M.K., BARROS, H.M.T., TANNHAUSER, S.L. \& TANNHAUSER. M. (1992) Meninos na rua: relação entre abuso de drogas e atividades lícitas. Revista ABP-APAL 14, 115-120.

FUNABEM (1987) Projeto de prevenção e redução de violência contra crianças e jovens. Rio de Janeiro: Coordenadoria de comunicação social.

LebesztanN, B., Kosin, M.D.. Prado, M.C.O. et al (1986) Avaliação do estado de saúde de menores de rua, na cidade de São Paulo. Acta AWHO, 5, 194-196.

Pedrozo, M.F.M. \& SigueirA, M.E.P.B. (1989) Solventes de cola: abuso e efeitos noctvos à saúde. Revisa Sauide pública. 23, 336-340.

John Dunn, Visiting Researcher (CNPq scholarship), Departemento de Psiquiatria, Escola Paulista de Medicina, Rua Botucatú, 740, São Paulo-SP, Brazil, 04023-900 